\title{
Evaluation of Mutagenesis, Necrosis and Apoptosis induced by Omeprazole in Stomach Cells of Patients with Gastritis
}

\section{Ana Maria Oliveira Ferreira da Mata}

Federal University of Piaui: Universidade Federal do Piaui

Marcia Fernanda Correia Jardim Paz

Federal university

Ag-Anne Pereira Melo de Menezes

Federal university

Antonielly Campinho dos Reis

federal university

\section{Bruna da Silva Souza}

Federal University of Rio Grande do Sul: Universidade Federal do Rio Grande do Sul

\section{Carlos Dimas de Carvalho Sousa}

Universidad Federada de Costa Rica

\section{Sônia Alves Machado}

Federal University of Piaui: Universidade Federal do Piaui

\section{Thiago Soares Gondim Medeiros}

Federal University of Piaui: Universidade Federal do Piaui

\section{Chhandan Sarkar}

Bangabandhu Sheikh Mujib Medical University

\section{Muhammad Torequl Islam}

Bangabandhu Sheikh Mujib Medical University

Javad Sharifi-Rad ( $\sigma$ javad.sharifirad@gmail.com )

Shahid Beheshti University of Medical Sciences School of Medicine https://orcid.org/0000-0002-73018151

\section{Sevgi Durna Daştan}

sivas cumhurity university

Mohammed M M Alshehri

Riyadha univesity

\section{João Marcelo de Castro e Sousa}

Federal University of Piaui: Universidade Federal do Piaui

\section{Ana Amélia de Carvalho Melo Cavalcante}

Federal University of Piaui: Universidade Federal do Piaui 
Primary research

Keywords: Citogenetic biomarkers, oxidative stress, apoptosis, genetic instability

Posted Date: November 2nd, 2021

DOI: https://doi.org/10.21203/rs.3.rs-1011505/v1

License: (c) (i) This work is licensed under a Creative Commons Attribution 4.0 International License. Read Full License

Version of Record: A version of this preprint was published at Cancer Cell International on April 18th, 2022. See the published version at https://doi.org/10.1186/s12935-022-02563-5. 


\section{Abstract}

Background: Gastritis is a superficial and prevalent inflammatory lesion that is considered a public health concernoncecause gastric ulcers and gastric cancer, especially due to Helicobacter pylori infection. Proton pump inhibitors, such as omeprazole, are the most widely used drugs in order to treat this illness. The aim of the study was evaluating the cytogenetic effects of omeprazole in stomach epithelial cells of patients with gastritis in presence and absence of $H$. pylori, using to this the application of cytogenetic biomarkers and measurements of catalse and superoxide dismutase.

Methods: The study included 152 patients from the Gastroenterology Outpatient Clinic of Hospital Getúlio Vargas, Teresina - Pl, that reported the continuous and prolonged use of omeprazole in doses of 20,30 and $40 \mathrm{mg} / \mathrm{kg}$. The participants were divided into groups: (1) patients without gastritis $(\mathrm{n}=32) ;(2)$ patients without gastritis but with use of OME $(n=24)$; (3) patients with gastritis $(n=26)$; (4) patients with gastritis undergoing OME therapy $(\mathrm{n}=26)$; (5) patients with gastritis and H. pylori $(\mathrm{n}=22)$ and $(6)$ patients with gastritis and H. pylori on OME therapy $(\mathrm{n}=22)$.

Results: OME induces cytogenetic risks in the epithelium of the stomach due to the formation of micronuclei (group 6>1,2,3,4,5; group 5>1,2,3; group 4>1,2,3); bridges (groups 4 and 6>1,2,3,5 and group $2>3,5$ ); buds (groups 2,4,6>,1,3,5); binucleated cells (group 6>1,2,3,4,5; group 4>1,2,3); groups 2 and $3>$ 1); picnoses (group 6>1,2,3,4,5), groups 2 and 5>1,3; group 4>1,2,3,5); cariorrexis (groups 6 and 4> 1,2,3,5; groups 2,3,5>1) and karyolysis (groups 2,4, and 6>1,3,5; groups 3 and $5>1$ ). These data show that omeprazole induces cytogenetic risks, especially due to infection with $H$. pylori, thus indicating the clastogenic and/or aneugenic effects, chromosomes changing, gene expression, cytotoxicity and apoptosis.

Conclusions: These risks can be attributed to several mechanisms that are still unclear, including oxidative damage, as observed by increases in catalase and superoxide dismutase. Positive correlations between these antioxidant enzymes were obtained with the formation of micronuclei, and negative for picnoses. Thus, the continuous and prolonged use of omeprazole induces genetic instability, which can be monitored, in cytogenetic analyzes, as anticipation for cancer, especially gastric.

\section{Introduction}

Gastric lesions, such as gastritis, cause damage to the integrity of the gastric or duodenal epithelium, producing ulcers and even cancer (Graham, 2014; Dias et al., 2015; Hong et al, 2017). Other gastric pathological changes may occur due to Helicobacter pylori (H. pylori) co-infection, that is able to increase the secretion of hydrochloric acid and pepsin by the gastric mucosa (Graham, 2014; Dias et al., 2015). Proton Pump Inhibitors (PPIs) such as Omeprazole (OME), lansoprasol, pantoprazole, esomeprazole, among others are used to minimize the effects of gastric acid by suppressing gastric acidity (Lahner et al, 2014; Savarinoet al., 2017; Minalyan et al., 2017), and have been used in continuous therapies (Haastrup et al., 2016; Numico et al., 2017). 
PPIs cause several adverse effects, however, there are reports that its prolonged use promotes cardiovascular and renal events, anemia, thrombocytopenia, and especially gastric polyps and carcinoma (Strand et al., 2017; Yu et al., 2017; Eusebi et al., 2017; Gesmundo et al., 2019), in addition can induce effects on DNA fragmentation (Shohda et al., 2015), causing chromosome rearrangements (Shankar et al., 2019), as well as breaks chromosomes, which can produce the formation of micronuclei (MN) (Rim and Kim, 2015; Bhatia and Kumar, 2013). Genotoxic compounds lead to the formation of MN (Alimbab and Oyeleke, 2015; Fenech et al., 2016) and to other types of nuclear alterations, such as apoptosis, cytoplasmic bridges and nuclear shoots (Fenech, 2007; Faria and Braga, 2015). Cytogenetic estimation of these changes is important for the analysis of several human diseases, as well as for the therapeutic monitoring of genotoxic agents (Holland et al., 2008; Sagari et al., 2014).

Metabolic products of drugs can produce genetic mutations, breaks and/or rearrangement of chromosomes. There are reports of cytotoxicity, hepatoxicity and carcinogenicity of OME metabolites (Shankar et al., 2019). Cytochrome P450 enzymes (CYPs) are able to act on the metabolism of PPIs (Denisenko et al., 2017), being considered as monoxygenases, responsible for the metabolism of several drugs, through expodification, hydrolization, desulfurization, dealkylation, oxidation or sulfoxidation reactions (Attia et al., 2019). OME is biotransformed in liver by the enzymatic action of CYP2C19 and CYP3A4 producing the metabolites 5-hydroxy $(5-\mathrm{OH})$ omeprazole and omeprazole Sulfona (Park et al., 2017).

In non-clinical studies, toxicogenic effects of OME were identified in Allium cepa (Braga et al., 2018), as well as oxidative effects in Saccharomyces cerevisiae and cytogenetics in Sarcoma 180 cells (Paz et al., 2019). Thus, in continuity with the previousinvestigations, the present study aimed to evaluate the possible cytogenetic damages of the use and/or therapy of OME in the gastric epithelium of patients with gastritis, with and without $H$. pylori infection, by the application of the micronucleus test and dosages of catalase and superoxide dismutase.

\section{Materials And Methods \\ 2.1 Ethical Aspects}

The present study was based on a controlled cross-sectional research, performed after the approvals of the Research Ethics Committees (CEP) of UNINOVAFAPI ( $\left.n^{\circ} 1.521 .307\right)$, Federal University of Piauí - UFPI $\left(n^{\circ} 1.607 .441\right)$ and Ethics Committee of Hospital Getúlio Vargas (No. 1,569,041). All participants agreed to participate voluntarily and signed the Free and Informed Consent Form (FICF), in accordance with resolution 466/12 of the National Health Council.

\subsection{Study Location and Population}

152 patients from the Gastroenterology Outpatient Clinic of Hospital Getúlio Vargas, Teresina - PI (20172019) participated of thisstudy. The participantshad been submmitedto the upper digestive endoscopy and reported the continuous use or not the of OME in doses of 20 and $40 \mathrm{mg} / \mathrm{Kg}$. Medical reports with 
information about the presence or absence of gastric diseases, including gastritis and H. pylori infection, were examined. The reports were provided by the hospital's doctors after the endoscopy and urea test. Participants were grouped according to the criteria: WG - patients without gastritis $(n=32)$; $W G+O M E$ patients without gastritis but with use of $\operatorname{OME}(n=24)$; $G$ - patients with gastritis $(n=26) ; G+O M E$ patients with gastritis and use of OME $(\mathrm{n}=26) ; \mathrm{G}+\mathrm{HP}$ - patients with gastritis and H. pylori $(\mathrm{n}=22)$ and $\mathrm{G}+\mathrm{HP}+\mathrm{OME}$ - patients with gastritis and H. pylori using OME $(\mathrm{n}=22)$.

\subsection{Inclusion and exclusion criteria}

The study included patients: 1) with or without gastritis; over 18 years old and legally responsible; 2) that were informed about the thestudy, its purposes, methods, probable benefits, potential risks and the discomfort that could cause them if they accept to participate ofinvestigation, after signing the informed consent form; 3 ) that needor not of prolonged treatment with OME, by medical recommendation or selfmedication, to solve gastric problems; 4) with free participation. The following participants were excluded: 1) that were notpart ofinclusion criteries; 2) over 70-year-old; 3) patients detected with illnesses that required surgical treatment, chemotherapy or radiotherapy.

\subsection{Data collection}

After The Free and Informed Consent Form signed, questionnaires were applied according to Carrano and Natarajam (1988), the protocol published by the International Commission for Environmental Protection against Mutagens and Carcinogens (ICPEMC), adaptations for approaches to nutritional aspects, sociocultural and health information and lifestyle of each patient were made. Exfoliated cells from the oral epithelium of patients undergoing endoscopy were obtained by scraping the inside of the cheek with the support of a cytobrush. Cells of gastric epithelium (region of the body and antrum of the stomach) were collected at the time of endoscopy by doctors. All samples were placed in tubes with sodium phosphate buffer (PBS) (50 mM, pH 7.4), properly identified, and transported in a styrofoam with ice to the Laboratory of Toxicological Genetics of the Federal University of Piauí, thus were immediately processed and tests carried out. Peripheral blood samples were collected with heparin, packed in ice and transported, similarly to the other samples. The urea test was performed by the hospital's medical team and the results were released together with the medical report.

\subsection{Micronucleus test on exfoliated cells of the stomach epithelium}

The Micronucleus Test was performed according to Thomas et al. (2009), with some adaptations. Samples of the epithelium of the stomach (antrum and body) were collected during the endoscopy by the doctors of the hospital. The material collected was placed in microtubes identified and previously prepared, containing $5 \mathrm{~mL}$ of saline solution $(0.9 \% \mathrm{NaCl})$. Immediately after obtention, the samples were sent to the Laboratory of Toxicological Genetics at the Federal University of Piauíin order topreparate the slides. With the purpose of minimize bacterial infection, and thus avoid complications in analysis,cell samples were washed three times before smear preparation. The washing process was carried out in 5 $\mathrm{mL}$ saline solution $(0.9 \% \mathrm{NaCl})$, with centrifugations for 10 minutes at $1500 \mathrm{rpm}$, followed by removal of 
the supernatant and replacement of the solution always in the final volume of $5 \mathrm{~mL}$. Two slides were prepared for each patient. After fixation, with methanol/acetic acid (3: 1), the slides were stained with $2 \%$ Giemsa. Then, the slides were washed twice in distilled water for 3 minutes and, finally, dried at room temperature. The incidence of micronuclei, nuclear buds, binucleated cells and nuclear abnormalities that represent cell death, carioretic, pycnotic and karyolitic cells, were observed in 2000 cells per patient with the use of optical microscopy, in the 1000x amplification, using oil of immersion.

\subsection{Evaluation of the profile of patients' enzymatic antioxidant defenses}

From the peripheral blood samples collected from the patients, $10 \%$ erythrocyte homogenates were prepared (50 mM sodium phosphate buffer $\mathrm{pH} 7.4$ ), which were centrifuged ( $800 \mathrm{~g}, 20 \mathrm{~min}$ ) and the supernatants used for assay of catalase (CAT) activities. The reaction medium was prepared with $\mathrm{H}_{2} \mathrm{O}_{2}$ $(18 \mathrm{~mL})$ plus $1 \mathrm{M}$ Tris $\mathrm{HCl}$ Buffer, $5 \mathrm{nM}$ EDTA pH $8.0(1.0 \mathrm{~mL})$ and $\mathrm{H} 20(0.8 \mathrm{~mL})$. Then, $980 \mu \mathrm{L}$ of the reaction medium and $20 \mu \mathrm{L}$ of the $10 \%$ erythrocyte homogenateprepared in $50 \mathrm{mM}$ sodium phosphate buffer, $\mathrm{pH} 7.4$, was placed in the quartz cuvette. Finally, the reading was performed in a spectrophotometer for 6 minutes at $230 \mathrm{~nm}$. The blank was made by reading the relative absorbance at $230 \mathrm{~nm}$ with only $1 \mathrm{~mL}$ of the reaction medium (Chance and Maehly, 1955). The protein concentration was determined (Lowry et al., 1951). The results were expressed in $\mathrm{mmol} / \mathrm{min} / \mathrm{mg}$ of protein. The homogenates of the $10 \%$ erythrocytes ( $50 \mathrm{mM}$ sodium phosphate buffer, $\mathrm{pH} 7.4$ ) were also centrifuged (800 g, $20 \mathrm{~min}$ ); and the supernatants used for superoxide dismutase (SOD) activity assessment. SOD activity was tested using the reduction rate of cytochrome $C$ by superoxide radicals, using the xanthinexanthine oxidase system as a source of superoxide anion (02-) (Arthur and Boyne, 1985). The results were expressed in $\mathrm{U} / \mathrm{mg}$ of protein. One unit $(\mathrm{U})$ of SOD activity corresponds to a $50 \%$ inhibition of the reaction of $02-$ with cytochrome $\mathrm{C}$. For the determination of protein concentration, the method of Lowry and collaborators (1951) was used.

\subsection{Urease test}

The evaluation of the presence of $\mathrm{H}$. pylori was performed by the urea test, according to UOTANI, T.; GRAHAM (2015). Samples of gastric epithelial mucosa (antrum and body) were collected by biopsy during endoscopy. The urease test was performed by the hospital's medical team and the result was obtained together with the endoscopy report.

\subsection{Statistical analysis}

The results of the analyzed biomarkers were presented as mean \pm the standard deviation from mean. The data obtained were evaluated using Analysis of Variance (ANOVA) followed by the Bonferroni test as a post hoc test. The data were analyzed using the GraphPad Prism 6.0 software (San Diego, CA, USA), the experimental groups were compared with the control group and with each other. Pearson's correlations were performed using the IBM SPSS Statistics 23 statistical program. $\mathrm{P}<0.05$ was defined as statistically significant. 


\section{Results}

After applying the questionnaire with approaches to nutritional aspects, socio-cultural, health and lifestyle information for each patient, by Carrano and Natarajam (1988), a protocol published by the International Commission for Environmental Protection against Mutagens and Carcinogens (ICPEMC), it was possible to complete the socio-cultural and health characterization of the population focused in this investigation (Table 1). The patients were aged 36-53 years old, mostly female, pardos, married and presented less than high school education complete. Most participants were not exposed to potentially mutagenic chemicals, such as pesticides, cleaning materials, dyes and solvents. However, it was observed that $64 \%$ of patients with $\mathrm{G}+\mathrm{OME}$ reported the exposure to cleaning products and $44 \%$ to pesticides. Patients informed also about don't practice physical exercises, as well about the low consumption of alcoholic beverages, smoking, consumption of meat and vegetables. In addition to, more than $50 \%$ of patients with gastritis, including those with positive results for $\mathrm{H}$. pylori, reported cases of cancer in family and the absence of hereditary diseases.

Regarding the mutagenic evaluation in cells of the stomach epithelium (antrum and body) of the patients, clastogenic and/or aneugenic effects were observed due to the formation of MN in WG + OME (3.62 \pm 1.81 ) and gastritis $(3,00 \pm 1.74)$, in relation to patients that don't have gastritis and were not taking OME as treatment $(1.62 \pm 0.83)$. Patients with $\mathrm{G}+\mathrm{OME}(5.091 \pm 1.71)$ also had more MN than those with gastritis and that were without OME therapy. The presence of H. pylori in patients with gastritis (5.09 \pm 1.71) also contributed to these effects, which in OME therapy induced an increase in the formation of $M N$ $(8.22 \pm 1.74)$, in relation to all study groups (Figure 1). There were no significant differences between patients with gastritis in relation to those without gastritis and who use $\mathrm{OME}$, as well as among those with $\mathrm{G}+\mathrm{HP}$ in relation to those with $\mathrm{G}+\mathrm{OME}$.

\section{Table 1}

Sociocultural and health characteristics of patients with gastritis and on omeprazole (OME) therapy at Getúlio Vargas Hospital. WG (Without Gastritis, $n=32$ ); (Without Gastritis + OME, $n=24$ ), G (Gastritis, $n=$ 26); $\mathrm{G}+\mathrm{OME}$ (Gastritis + OME, $\mathrm{n}=26), \mathrm{G}+\mathrm{HP}$ (Gastritis + H. pylori, $\mathrm{n}=22) ; \mathrm{G}+\mathrm{HP}+\mathrm{OME}$ (Gastritis + H. pylori $+\mathrm{OME}, \mathrm{n}=22)$. ** The term pardo refers to Brazilians of mixed ethnic ancestries. 


\begin{tabular}{|c|c|c|c|c|c|c|}
\hline Parameters & $\begin{array}{l}\text { WG } \\
(n=26)\end{array}$ & $\begin{array}{l}G \\
(n=23)\end{array}$ & $\begin{array}{l}G+H P \\
(n=16)\end{array}$ & $\begin{array}{l}\text { WG + } \\
\text { OME } \\
(n=22)\end{array}$ & $\begin{array}{l}G+O M E \\
(n=25)\end{array}$ & $\begin{array}{l}\text { G+HP+OME } \\
(n=25)\end{array}$ \\
\hline \multicolumn{7}{|l|}{ Gender (\% valid) } \\
\hline Male & 26.9 & 34.8 & 50.0 & 40.9 & 44.0 & 12.0 \\
\hline Female & 73.1 & 65.2 & 50.0 & 59.1 & 56.0 & 88.0 \\
\hline \multicolumn{7}{|l|}{ Ethnic Groups (\% valid) } \\
\hline White & 11.5 & 17.4 & 12.5 & 27.3 & 20.0 & 48.0 \\
\hline Pardo ** & 57.70 & 56.5 & 62.5 & 63.6 & 64.0 & 36.0 \\
\hline Black & 30.8 & 26.1 & 25.0 & 4.5 & 16.0 & 16.0 \\
\hline $\mathrm{Age}(\mathrm{MD} \pm \mathrm{DV})$ & $\begin{array}{l}48.46 \pm \\
13.98\end{array}$ & $\begin{array}{l}53.57 \pm \\
17.08\end{array}$ & $\begin{array}{l}39.81 \pm \\
17.17\end{array}$ & $\begin{array}{l}36.36 \pm \\
11.99\end{array}$ & $\begin{array}{l}51.48 \pm \\
11.99\end{array}$ & $\begin{array}{l}51.40 \pm \\
13.21\end{array}$ \\
\hline Weight (Kg) (MD $\pm \mathrm{DV})$ & $\begin{array}{l}60.31 \pm \\
9.39\end{array}$ & $\begin{array}{l}62.78 \pm \\
13.54\end{array}$ & $\begin{array}{l}67.20 \pm \\
14.65\end{array}$ & $\begin{array}{l}62.40 \pm \\
8.42\end{array}$ & $\begin{array}{l}66.73 \pm \\
11.76\end{array}$ & $\begin{array}{l}68.44 \pm \\
8.99\end{array}$ \\
\hline \multicolumn{7}{|l|}{ Marital status (\% valid) } \\
\hline Married & 42.3 & 30.4 & 37.5 & 45.5 & 60.0 & 60.0 \\
\hline Divorced & 11.5 & 26.1 & 25.0 & 4.5 & 8.0 & 28.0 \\
\hline Single & 30.8 & 26.1 & 37.5 & 50.0 & 20.0 & - \\
\hline Widowed & 15.4 & 17.4 & - & - & 12.0 & 12.0 \\
\hline \multicolumn{7}{|l|}{$\begin{array}{l}\text { Education Level (\% } \\
\text { valid) }\end{array}$} \\
\hline $\begin{array}{l}\text { Without education level } \\
\text { complete }\end{array}$ & 11.5 & - & 31.3 & 18.2 & 20.0 & 12.0 \\
\hline Elementery & 19.2 & 52.2 & 6.3 & 31.8 & 24.0 & 12.0 \\
\hline Elementery(incomplete) & 19.2 & 17.4 & 50.0 & 36.4 & 12.0 & 52.0 \\
\hline High school & 13.8 & 8.7 & - & - & 16.0 & 12.0 \\
\hline $\begin{array}{l}\text { High school } \\
\text { (incomplete) }\end{array}$ & - & 8.7 & - & - & - & - \\
\hline $\begin{array}{l}\text { Bachelor } \\
\text { Bachelor (incomplete) }\end{array}$ & - & - & - & 9.1 & - & - \\
\hline \multicolumn{7}{|l|}{$\begin{array}{l}\text { Chemical Exposure (\% } \\
\text { valid) }\end{array}$} \\
\hline Cledining & 15.4 & 13.0 & 12.0 & - & 44.0 & 12.0 \\
\hline
\end{tabular}




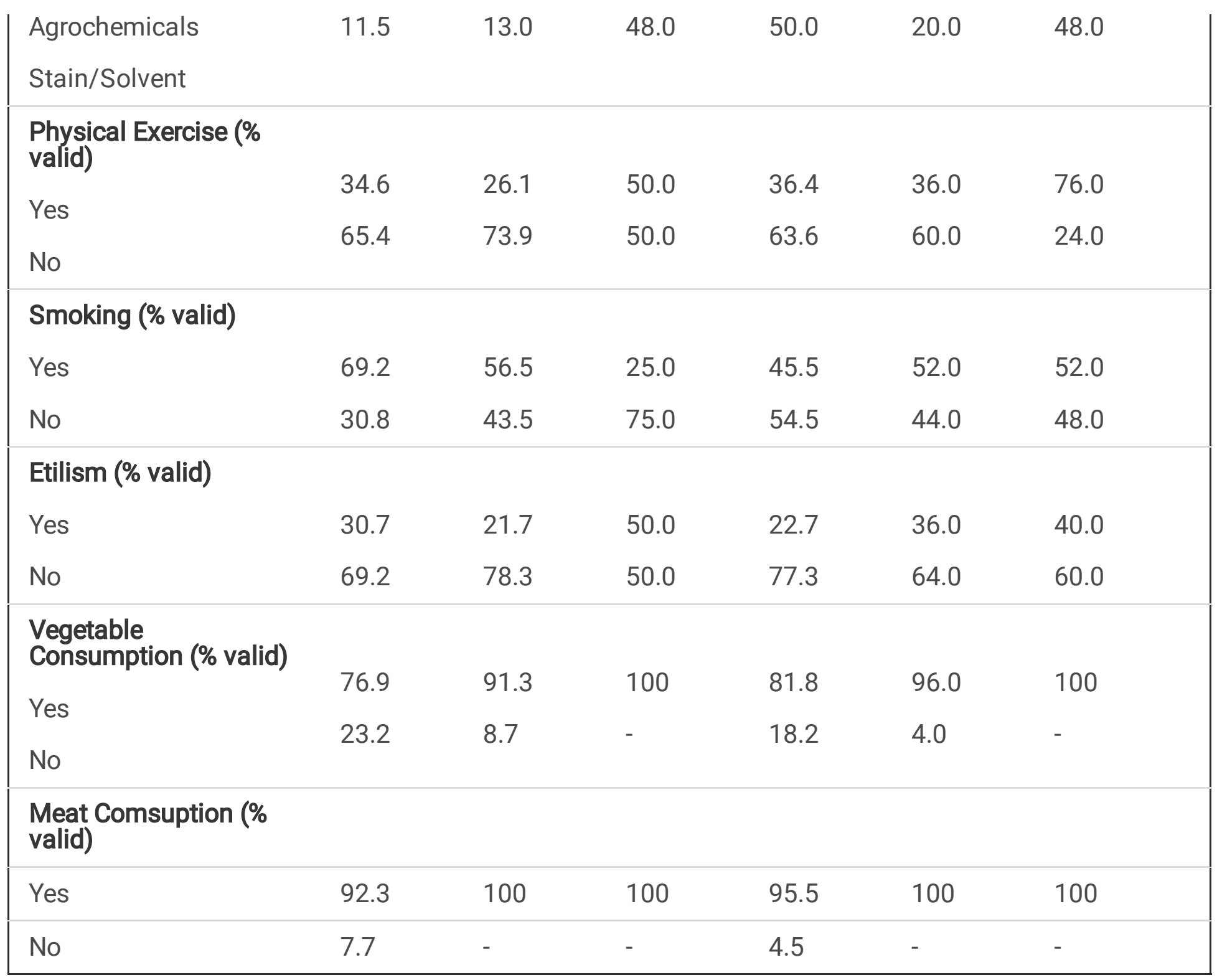

OME therapy wasable to induce others nuclear alterations such as buds and nucleoplasmic bridges on the epithelium of the stomach (body and antrum) (Figure 2). Increases in the number of buds were observed in patients without gastritis $(11.67 \pm 4.26)$ and with gastritis $(12.08 \pm 4.26)$ when compared with patients without gastritis and that use OME as medicine to treatment $(1.78 \pm 1,09)$. The presence of H. pylori in patients with gastritis $(3.69 \pm 2.80)$ was not able to induce an increase in buds in relation to those with gastritis without use of OME $(2.13 \pm 1.80)$, but when in therapy with OME (13.73 \pm 2.25$)$, an increase of this nuclear alteration was detected, indicating effects on expression and genes (Figure $2 \mathrm{~A}$ ).

In relation to nucleoplasmic bridges, it was observed that OME induced an increase in patients without gastritis $(10,55 \pm 2.52)$ and with gastritis $(12.69 \pm 2.96)$ when compared to the group without gastritis and that use OME $(2.03 \pm 1.42)$. In patients with gastritis $(3.73 \pm 1.82)$ and gastritis and H. pylori $(3.65 \pm$ 2.01), it was not seen an increase in nucleoplasmic bridges in relation to the group without gastritis and wichwere not using OME. However, in patients with H. pylori and on OME therapy (13.59 \pm 3.99)intensifications in nuclear abnormalities were detected (Figure 2B). 
The use and/or therapy with OME was able to induce the cytotoxic effects by increasing binucleated cells in patients without gastritis and in patients that used the medicinewithout medical advice $(5.44 \pm 2.14)$, also in patients with gastritis $(7.11 \pm 3.97)$, as well as as in patients with gastritis and positive for $H$. pylori $(20,41 \pm 3.15)$, when compared to patients without gastritis and who do not use OME $(2.33 \pm 0.91)$. Similarly in patients with gastritis and $H$. pylori $(5.01 \pm 1.27)$ that were not proceeding therapy. Likewise, in patients with gastritis without use and/or use of OME therapy (4.23 \pm 1.25$)$, an increase in binucleated cells was observed (Figure 3A).

OME also induced cytotoxic effects by the formation of pycnotic cells in patients without gastritis and that use OME as medicine $(13.96 \pm 5.17)$ and in patients with gastritis submitted to OME therapy (18.46 \pm 4.32), as well as in patients that are not using the medicine, but positive for $H$. pylori $(7.84 \pm 3.16)$ and in positive patients and wich were undergoing therapy $(23,36 \pm 8.72)$, when compared to patients without gastritis and are not using OME $(1,61 \pm 0.61)$ (Figure 3B).

Similar to observed for binucleated and pycnotic cells, OME was able to induce apoptotic effects by nuclear fragmentation (cariorrexe) in stomach epithelium cells in patients without gastritis $(202.20 \pm$ $69.65)$, and with gastritis and without $(232,60 \pm 93.63)$ or with $H$. pylori $(209,40 \pm 78.06)$, when compared to patients without gastritis and wichwere not taking OME $(150.00 \pm 49.02)$. The presence of H. pylori in patients with gastritis and on OME therapy $(291,10 \pm 70.20)$ also induced an increase in cariorrexis (Figure 4A). Apoptotic effects of OME by nuclear dissolution (karyolysis) were similarly observed in epithelial cells of the stomach in patients without gastritis $(366.30 \pm 108.60)$, with gastritis in therapy $(359.00 \pm 120.20)$ and with gastritis and H. pylori in therapy $(397.80 \pm 140.50)$ in relation to patients without gastritis and were not taking OME $(149.90 \pm 46.32)$. However, these effects were also observed in patients with gastritis $(324.20 \pm 179.40)$ and with gastritis and $H$. pylori $(258.00 \pm 122.70)$ wich were not using OME therapy (Figure 4B).

In the study, it was observed that OME induces changes in dosages of antioxidant enzymes such as catalase and superoxide dismutase (Figure 5). In patients without and with gastritis wich had been in therapy or were in therapy, as well as in patients with gastritis without and with gastritis and H. pylori, they presented catalase increases in relation to patients without gastritis and were not taking OME (Figure 5A). However, patients with gastritis and H. pylori on OME therapy showed a superior increase in catalase compared to the other groups. The data for superoxide dismutase were similar to those observed for catalase (Figure 5B).

In patients with gastritis and $\mathrm{H}$. pylori on OME therapy, positive correlations were observed between micronucleus induction with catalase and superoxide dismutase measurements, and negative ones for picnoses induction (Figure 6).

\section{Discussion}

In the present study, it was observed that the use and/or therapy with omeprazole (OME) in a continuous and prolonged manner, without dose specifications $(20,30$ and $40 \mathrm{mg} / \mathrm{Kg})$ can cause cytogenetic risks 
in cells of the stomach epithelium, byaneugenic and/or clastogenic effects, by inducing micronuclei in patients without gastritis but use the drug, and with gastritis and in therapy, when compared to patients that neither use the medicine and even not in therapy with other drugs. The effects of OME on the formation of micronuclei in human cells are still unwell described. However, there are in silico studiessuggesting that OME can lead to chromosomal changes, as well as contribute to the formation of micronuclei (Rosenkranz and Kjopman, 1991), also promoting covalent connection with DNA, characterizing its genotoxicity (Phillips et al., 1992).

Investigations in gastric epithelial cells of patients with gastritis and with positive results for H. pylori, indicates a risk of genotoxicity, with greater significance in relation to negative patients (Marie and Altahir, 2011), as well as was observed in the study in relation to the formation of micronuclei, in epithelial cells of the stomach. H. pylori infections can cause chronic gastritis, peptic and duodenal ulcers, adenocarcinoma and gastric lymphoma (Trindade et al., 2017). There are reports that OME can induce DNA damage, after its metabolism, by the formation of $\mathrm{N}$-nitrosamines that can generate several nuclear alterations such as MN, pycnosis and cariorrexis (Thongon and Krishnamra, 2011; Novotna et al., 2014). MN can also be provokedby chromosome breaks (Rim and Kim, 2015), or by internal chromosomes that have been separated from the nucleus (Balmus et al., 2015), due to breaks in the double-stranded DNA or as a result of mitotic spindle dysfunction (Fenech, 2007; Fenech et al., 2011). It is taken in consideration that DNA breaks can happen due to oxidative stress (Fang et al., 2015) inducing apoptosis (Pittaluga et al., 2015).

DNA damage, like cytogenetics, can be induced by OME after its metabolism by the production of sulfone, sulfite and hydroxy-omeprazole (Rosenkranz and Kjopman, 1991; Downes and Foster, 2015), as also for its electrophilic potential (Powers et al., 1995) due to covalent bonds with DNA (Burlinson et al., 1990; Furihata et al., 1991). It is observed that OME can increase nuclear cell proliferation antigens (PCNA) (Liu et al., 2016; Zheng et al., 2016), by modulating via lysosomal transport with mechanisms of expression of the LC3 gene associated to autophagy (Udelnow et al., 2011).

In addition to the formation of micronuclei, other cytogenetic risks were observed in the cells of the stomach epithelium of patients without gastritis and with gastritis (without and with H. pylori infection, in and/or OME therapy, such as nucleoplasmicbuds and bridges,the buds are the result of DNA amplification or repair (Fenech et al, 2011; Luzhna, 2013) and the bridges are originated from failures in chromosomal rearrangements or are result from the fusion of chromosomal ends, telomeres that allow the formation of filaments chromatin molecules that link two distinct nuclei (Fenech et al., 2011). Corroborating findings observed in this study, there are previous reports that OME can induce changes in chromosomes and micronucleus formation (Burlinson et al., 1990; Rosenkranz and Kjopman, 1991; Furihata et al., 1991).

The cytotoxicity of OME has been reported in normal human cells (HEK293 and NIH3T3) (Shankar et al., 2019). In cells of the stomach epithelium of patients, that use or are in therapy with OME, cytogenetic risks are indicative of cytotoxicity, due to the induction of picnoses and binucleated cells, especially in 
patients with $H$. pylori infection. H. pylorliberatesa cytotoxin that can provoke apoptosis by alterations in the release of cytochrome $C$ in mitochondria (Gajewski et al., 2016), as well as can destroy the cellular junctions in the gastric epithelium (Alzahrani et al., 2014), causing transient enlargement acid secretion leading to hypochlorhydria and intestinal metaplasia (Trindade et al., 2017). These events are linked to a risk of gastric adenocarcinomas development (Keilberg and Ottemann, 2016; Wessler et al., 2017). It's necessary takes in considerarion that picnoses occur due to chromatin condensation and dissolution, and binucleated cells result from cytokinesis failures at the end of cell division (Sabharwal et al., 2015).

However, it is needed emphasize that OME has hepatotoxic effects (Cesário et al., 2015) as a result of apoptosis mechanisms by inducement of tumor necrosis factor alpha (TNF-a) (Fontana et al., 2014), as well as by alterations of liver enzymes AST and ALT (Thomas et al., 2016). There is also informationabout organ toxicity (hepatotoxicity), toxicological parameters (Banerjee et al., 2018), hepatotoxicity in pregnant women, observed by the reduction of the enzymes AST and ALT (Thomas et al., 2016) and hepatotoxic and nephrotoxic effects as thrombocytopenia, acute interstitial nephritis, anaphylactic reactions and gynecomastia (Cesário et al., 2015). The by-products OMP-1, OMP-6, OMP-7, OMP-8, OMP-13 and OMP-15 can also combine with the aryl hydrocarbon receptor (AhR) and induce toxic effects to the immune system (Shankar et al., 2019).

In this study, OME induced apoptosis in stomach epithelial cells due to cytogenetic risks of nuclear fragmentation (cariorrexis) and nuclear dissolution (karyolysis), as seen in patients without gastritis and with gastritis in use and/or therapy with OME, with significance also in patients with $\mathrm{H}$. pylori infection, as previously observed in other nuclear alterations. It is necessary mentionate that the induction of apoptosis is one of the mechanisms linked to of acute gastric injury (Lou et al., 2013), however, OME has apoptotic effects in human gastric cancer cells (HGC-27) (Zhazg et al., 2013), colorectal tumor cells (Muerkoster et al., 2008; Kim et al., 2010) and normal human nuclear polymorphic leukocytes (Capodicasa et al., 2018).

According to other investigations, drugs that induce oxidative damage may increase the levels of endogenous enzymes associatedto antioxidant defenses such as catalase and superoxide dismutase (Almenara et al., 2015; Herbet et al., 2016; Poprac et al., 2017). Catalase (CAT) is one of the antioxidant enzymes that have participation in degradation of $\mathrm{H}_{2} \mathrm{O}_{2}$ through dismutation reactions, current mainly in the peroxisomes of cells and helps to protect against damage caused by hydrogen peroxide, been considered as an important oxidative biomarker (Pey et al., 2017; Gupta et al., 2012). Superoxide dismutase (SOD) converts the oxygen produced during oxidative stress to $\mathrm{H}_{2} \mathrm{O}_{2}$. In this way, to act effectively in maintaining cellular integrity and function, SOD depends on the balance between SOD, GPX and CAT (Pey et al., 2017).

In this study it was possible to detect an increase in antioxidant defenses for these enzymes, especially in patients with $H$. pylori infection. $H$. pylori infection can also increase the production of reactive oxygen and nitrogen species in the stomach (Golbabapour et al., 2013). However, gastric lesions can induce oxidative stress, with amplification by OME therapy (Kohler et al., 2010) independently of co-infection 
with $H$. pylori, and may also induce an increase in antioxidant enzymes such as SOD and CAT, and glutathione reductase (GSH) (Baldissera and Cruzat, 2014; Glorieux and Calderon, 2017). Drugs contribute to increase oxidative stress levels (Herbet et al., 2016; Almenara et al., 2015; Porto et al., 2015), due to an imbalance between antioxidant defenses and oxidative stress levels (Gunasekarana et al., 2015) and regulation of lipid peroxidation (Ward et al., 2015).

OME is one of the drugs that can induce oxidative stress (Kohler et al., 2010), which culminates in cell apoptosis (Woúniak et al., 2017; Pey et al., 2017; Sies et al., 2017). Free radicals induce gastric lesions (Sofidiya et al., 2012), and that this process can contribute to carcinogenesis (Tsuchiya et al., 2018). Gastric lesions can produce free radicals, which are minimized by enzymes SOD and GPx, which lead to tissue recovery and gastroprotection (Cheng et al., 2014; Chen et al., 2014). OME can also induce lipid peroxidation, with responses to the increase in catalase and superoxide dismutase, and can also be considered as a marker of oxidative stress (Chen et al., 2014).

During its metabolism, OME can generate sulfone, sulfite and hydroxy-omeprazole, compounds that can generate more oxidative damage to genetic material (Brambilla et al., 2010; Brambilla and Martelli, 2009; Downes and Foster, 2015). OME are able to induce an increase of enzyme heme-oxigenease by means independent of the aryl hydrocarbon receptor (AhR), which consequently increases the levels of $\mathrm{H}_{2} \mathrm{O}_{2}$ (Patel et al., 2012). Oxidative damage can be one of the OME mechanisms for inducing changes in genetic material in gastric epithelium cells, as it can produce $\mathrm{H}_{2} \mathrm{O}_{2}$ when it binds to protein $\mathrm{C} 283$, which contains CACT, and C136 generating beta oxidation of fatty acids (Tonazzi et al., 2013). OME can induce oxidative damage in S. cerevisiae, in addition to cytogenetic damage in Sarcoma 180 cells (Paz et al., 2019).

Among these mechanisms, the study points out that the cytogenetic risks that can be induced by oxidative effects that lead to the formation of micronuclei and other nuclear alterations indicative of cytotoxicities and apoptosis. Corroborating these analyzes, positive and negative statistical correlations were observed between micronuclei and the measurements of CAT and SOD, and between pyknosis, respectively. Proton pump inhibiting drugs (PPIs), such as $\mathrm{OME}$, may have genotoxic and/or carcinogenic effects (Downes and Foster, 2015), through several mechanisms including oxidative stress. When the substances that induce oxidative stress are in excess and the antioxidant system is unable to neutralize the oxidative process (Laskoski et al., 2016), several cellular mechanisms induce cell regulation and activation of signaling cascades for cell death (apoptosis or necrosis) (Woźniak et al., 2017), for cell proliferation, metastasis, resistance to apoptosis, angiogenesis and as a consequence of genetic instability (Moloney and Cotter, 2017). A possible mechanism of OME has been shown in Figure 7.

\section{Conclusions}

In this study, in cells of the stomach epithelium of patients without gastritis and with gastritis, especially those with H.pylori infection, in use and/or therapy with OME, it was possible to point out that $\mathrm{OME}$ induces cytogenetic risks due to (1) clastogenic effects and/or aneugenic by inducing micronucleus 
increases; (2) in gene expression and chromosomal rearrangements or fusion of chromosomal ends; (3) cytotoxic by inducing increases in picnoses and binucleated cells and (4) apoptotic by increasing karyorexis and karyolysis. Several mechanisms, not yet elucidated, can be attributed to these cytogenetic effects of OME, but oxidative effects can also be involved, as observed by the increase in dosages of endogenous enzymes of antioxidant defenses such as catalse and superoxide dismutase, which have also been associatedto the increase of micronuclei and picnoses. These data point to more attention regarding the use and/or therapy with $\mathrm{OME}$, as well as the monitoring of cytogenetic changes and oxidative damage, as an important strategy for the prevention of genetic instability.

\section{Declarations}

\section{- Ethics approval and consent to participate:}

Not Applicable

- Consent for publication:

Not Applicable

- Availability of data and materials:

Yes

\section{- Competing interests:}

No Competing Interest

\section{- Funding:}

No Funding received but Will Pay the APC

\section{- Authors' contributions:}

The work was supervised by Muhammad Torequl Islam, Javad Sharifi-Rad and Ana Amélia de Carvalho Melo Cavalcante. Project administration, Final draft of the work, by Ana Maria Oliveira Ferreira da Mata, Marcia Fernanda Correia Jardim Paz, Ag-Anne Pereira Melo de Menezes, Antonielly Campinho dos Reis, Bruna da Silva Souza, Carlos Dimas de Carvalho Sousa, Sônia Alves Machado, Thiago Soares Gondim Medeiros, Chhandan Sarkar, Muhammad Torequl Islam, Javad Sharifi-Rad, João Marcelo de Castro e Sousa, Ana Amélia de Carvalho Melo Cavalcante.

\section{- Acknowledgement}


We are owed to RENORBIO and UFPI for funding and hosting, respectively of this project.

\section{References}

1. Adeoye, G. O., Alimba, C. G., and Oyeleke, O. B. (2015). The genotoxicity and systemic toxicity of a pharmaceutical effluent in Wistar rats may involve oxidative stress induction. Toxicol. Rep.2, 12651272. doi: 10.1016/j.toxrep.2015.09.004

2. Almenara, C. C., Mill, J. G., Vassallo, D. V., Baldo, M. P., and Padilha, A. S. (2015). In vitro fructose exposure overactivates NADPH oxidase and causes oxidative stress in the isolated rat aorta. Toxicol. In Vitro 29, 2030-2037.doi: 10.1016/j.tiv.2015.08.013

3. Alzahrani, S., Lina, T. T., Gonzalez, J., Pinchuk, I. V., Beswick, E. J., and Reyes, V. E. (2014). Effect of Helicobacter pylori on gastric epithelial cells. World J. Gastroenterol. 20, 12767-12780. doi: 10.3748/wjg.v20.i36.12767

4. Arthur, J. R., and Boyne, R. (1985). Superoxide dismutase and glutathione peroxidase activities in neutrophils from selenium deficient and copper deficient cattle. Life Sci. 36, 1569-1575. doi: 10.1016/0024-3205(85)90381-9

5. Attia, T. Z., Yamashita, T., Tsujino, H., Derayea, S. M., Tsutsumi, Y., \& Uno, T. (2019). Effect of Drug Combination on Omeprazole Metabolism by Cytochrome P450 2C19 in Helicobacter pylori Eradication Therapy. Chem. Pharm. Bull. 67(8), 810-815. doi: 10.1248/cpb.c19-00084

6. Baldissera, F. G., and Cruzat, V. F. (2014). Estresse oxidativo, qualidade de vida e exercício: uma abordagem nutricional. Atenção Integral à Saúde.

7. Balmus, G., Karp, N. A., Ng, B. L., Jackson, S. P., Adams, D. J., and Mclntyre, R. E. (2015). A highthroughput in vivo micronucleus assay for genome instability screening in mice. Nat. Protoc.10 (1), 205-215. doi: 10.1038/nprot.2015.010

8. Banerjee, P., Eckert, A. O., Schrey, A. K., and Preissner, R. (2018). ProTox-II: a webserver for the prediction of toxicity of chemicals. Nucleic Acids Res. 46, W257-W263. doi: 10.1093/nar/gky318

9. Bellone, M., Calcinotto, A., Filipazzi, P., De Milito, A., Fais, S., and Rivoltini, L. (2013). The acidity of the tumor microenvironment is a mechanism of immune escape that can be overcome by proton pump inhibitors. Oncoimmunology2 (1), e22058. doi: 10.4161/onci.22058

10. Braga, A. L., de Meneses, A. A. P. M., de Oliveira Santos, J. V., Dos Reis, A. C., de Lima, R. M. T., da Mata, A. M. O. F., et al. (2018). Toxicogenetic study of omeprazole and the modulatory effects of retinol palmitate and ascorbic acid on Allium cepa. Chemosphere204, 220-226.doi: 10.1016/j.chemosphere.2018.04.021

11. Brambilla, G., and Martelli, A. (2009). Genotoxicity and carcinogenicity studies of analgesics, antiinflammatory drugs and antipyretics. Pharmacol. Res. 60 (1), 1-17. doi: 10.1016/j.phrs.2009.03.007

12. Brambilla, G., Mattioli, F., and Martelli, A. (2010). Genotoxic and carcinogenic effects of gastrointestinal drugs. Mutagenesis 25 (4), 315-326.doi:10.1093/mutage/geq025 
13. Brzozowski, T., Ptak-Belowska, A., Kwiecien, S., Krzysiek-Maczka, G., Strzalka, M., Drozdowicz, D., et al. (2012). Novel concept in the mechanism of injury and protection of gastric mucosa: role of reninangiotensin system and active metabolites of angiotensin. Curr. Med. Chem.19 (1), 55-62. doi:10.2174/092986712803413953

14. Brzozowski, T., Konturek, P. C., Pajdo, R., Ptak-Belowska, A., Kwiecien, S., Pawlik, M., et al. (2008). Physiological mediators in nonsteroidal anti-inflammatory drugs (NSAIDs)-induced impairment of gastric mucosal defense and adaptation. Focus on nitric oxide and lipoxins. J. Physiol. Pharmacol. $59,89-102$.

15. Burlinson, B., Morriss, S. H., Gatehouse, D. G., Tweats, D. J., Ekman, L., Bolcsfoldi, G., et al. (1990). Genotoxicity studies of gastric acid inhibiting drugs. The Lancet 335 (8686), 419-420. doi:10.1016/0140-6736(90)90260-C

16. Canitano, A., lessi, E., Spugnini, E. P., Federici, C., and Fais, S. (2016). Proton pump inhibitors induce a caspase-independent antitumor effect against human multiple myeloma. Cancer Lett. 376 (2), 278283. doi:10.1016/j.canlet.2016.04.015

17. Capodicasa, E., Cornacchione, P., Natalini, B., Bartoli, A., Coaccioli, S., Marconi, P., and Scaringi, L. (2008). Omeprazole induces apoptosis in normal human polymorphonuclear leucocytes. Int. J. Immunopathol. Pharmacol. 21 (1), 73-85. doi:10.1177/039463200802100109

18. Carrano, A. V., and Natarajan, A. T. (1988). Considerations for population monitoring using cytogenetic techniques. Mutat. Res.204 (3), 379-406. doi:10.1016/0165-1218(88)90036-5

19. Cesário, M. R., Barros, B. S., Courson, C., Melo, D. M., and Kiennemann, A. (2015). Catalytic performances of $\mathrm{Ni}-\mathrm{CaO}-$ mayenite in $\mathrm{CO} 2$ sorption enhanced steam methane reforming. Fuel Process. Technol.131, 247-253.doi:10.1016/j.fuproc.2014.11.028

20. Chance, B., and Maehly, A. C. (1955). [136] Assay of catalases and peroxidases. Meth. Enzymol. 2, 764-775. doi:10.1016/s0076-6879(55)02300-8

21. Chen, C., Arjomandi, M., Qin, H., Balmes, J., Tager, I., and Holland, N. (2006). Cytogenetic damage in buccal epithelia and peripheral lymphocytes of young healthy individuals exposed to ozone. Mutagenesis 21 (2), 131-137. doi:10.1093/mutage/gel007

22. Cheng, Y. T., Wu, S. L., Ho, C. Y., Huang, S. M., Cheng, C. L., and Yen, G. C. (2014). Beneficial effects of camellia oil (Camellia oleifera Abel.) on ketoprofen-induced gastrointestinal mucosal damage through upregulation of HO-1 and VEGF. J. Agric. Food Chem. 62 (3), 642-650. doi:10.1021/jf404614k

23. Denisenko, N. P., Sychev, D. A., Sizova, Z. M., Smirnov, V. V., Ryzhikova, K. A., Sozaeva, Z. A., and Grishina, E. A. (2017). Urine metabolic ratio of omeprazole in relation to CYP2C19 polymorphisms in Russian peptic ulcer patients. Curr Pharmacogenomics Person. Med. 10, 253-259. doi:10.2147/PGPM.S141935

24. Dias, N., Santos, P., Pinto, M., Fernandes, C., Júnior, A., Souza, S., et al. (2015). Análise de prontuários de pacientes com gastrite em um hospital na região oeste ii do estado de Goiás. Rev. eletrônica Fac. Montes Belos8 (1), 1-9. 
25. Downes, N., and Foster, J. (2015). Regulatory forum opinion piece: carcinogen risk assessment: the move from screens to science. Toxicol. Pathol. 43(8), 1064-1073.doi:10.1177/0192623315598578

26. El-Maraghy, S. A., Rizk, S. M., and Shahin, N. N. (2015). Gastroprotective effect of crocin in ethanolinduced gastric injury in rats. Chem. Biol. Interact. 229, 26-35. doi:10.1016/j.cbi.2015.01.015

27. Esteva, F., Iñarrea, P., Cornudella, R., and Lanas, A. (1998). Omeprazole does not interfere with the antiplatelet effect of low dose aspirin in man. Gastroenterology 114, A116.doi:10.1016/s00165085(98)80473-3

28. Eusebi, L. H., Rabitti, S., Artesiani, M. L., Gelli, D., Montagnani, M., Zagari, R. M., and Bazzoli, F. (2017). Proton pump inhibitors: risks of long-term use. J. Gastroenterol. Hepatol.32 (7), 1295-1302. doi:10.1111/jgh.13737

29. Fang, H. M., Wang, J. J., Zhang, L. J., Xu, J. M., Mei, Q., Lu, C. X. (2013). Omeprazole and rabeprazole azole effect on rat intestinal P-glycoprotein. Chin. J. Hosp. Pharm.33, 7-11.

30. Faria, L. E. M., and Braga, J. R. M. (2015). Aplicação do teste de micronúcleo para avaliação de potencial genotóxico em epitélio oral de estudantes universitários. Rev. Eletrôn. Atualiza Saúde 1 (1), 35-41.

31. Fenech, M. (2007). Cytokinesis-block micronucleus cytome assay. Nat. Protoc. 2 (5), 1084. doi:10.1038/nprot.2007.77

32. Fenech, M., Kirsch-Volders, M., Natarajan, A. T., Surralles, J., Crott, J. W., Parry, J., et al. (2011). Molecular mechanisms of micronucleus, nucleoplasmic bridge and nuclear bud formation in mammalian and human cells. Mutagenesis26 (1), 125-132. doi:10.1093/mutage/geq052

33. Fenech, M., Knasmueller, S., Bolognesi, C., Bonassi, S., Holland, N., Migliore, L., et al. (2016). Molecular mechanisms by which in vivo exposure to exogenous chemical genotoxic agents can lead to micronucleus formation in lymphocytes in vivo and ex vivo in humans. Mutat. Res. Rev. Mutat. Res. 770, 12-25.doi:10.1016/j.mrrev.2016.04.008

34. Fontana, R. J., Hayashi, P. H., Gu, J., Reddy, K. R., Barnhart, H., Watkins, P. B., et al. (2014). Idiosyncratic drug-induced liver injury is associated with substantial morbidity and mortality within 6 months from onset. Gastroenterol. 147 (1), 96-108. doi:10.1053/j.gastro.2014.03.045

35. Furihata, C., Hirose, K., and Matsushima, T. (1991). Genotoxicity and cell proliferative activity of omeprazole in rat stomach mucosa. Mutat. Res. Lett. 262 (1), 73-76. doi: 10.1016/01657992(91)90109-H

36. Gajewski, A., Mnich, E., Szymański, K., Hinc, K., Obuchowski, M., Moran, A. P., and Chmiela, M. (2016). Helicobacter pylori antigens, acetylsalicylic acid, LDL and 7-ketocholesterol-their potential role in destabilizing the gastric epithelial cell barrier. An in vitro model of Kato III cells. Acta Biochim. Pol. 63 (1), 145-152. doi: 10.18388/abp.2015_1122

37. Gesmundo, I., Di Blasio, L., Banfi, D., Villanova, T., Fanciulli, A., Favaro, E., et al. (2019). Proton pump inhibitors promote the growth of androgen-sensitive prostate cancer cells through ErbB2, ERK1/2, PI3K/Akt, GSK-3 $\beta$ signaling and inhibition of cellular prostatic acid phosphatase. Cancer lett. 449, 252-262. doi: 10.1016/j.canlet.2019.02.028

Page 17/28 
38. Glorieux, C., and Calderon, P. B. (2017). Catalase, a remarkable enzyme: targeting the oldest antioxidant enzyme to find a new cancer treatment approach. Biol. Chem., 398(10), 1095-1108.

39. Golbabapour, S., Hajrezaie, M., Hassandarvish, P., Abdul Majid, N., Hadi, A. H. A., Nordin, N., and Abdulla, M. A. (2013). Acute toxicity and gastroprotective role of M. pruriens in ethanol-induced gastric mucosal injuries in rats. Biomed Res. Int. 2013. doi: 10.1155/2013/974185

40. Graham, D. Y. (2014). History of Helicobacter pylori, duodenal ulcer, gastric ulcer and gastric cancer. World J. Gastroenterol. 20 (18), 5191-5204. doi: 10.3748/wjg.v20.i18.5191

41. Gunasekarana, V., Raj, G. V., \& Chand, P. (2015). A comprehensive review on clinical applications of comet assay. J. Clin. Diagn. Res. 9 (3), GE01-GE05.doi: 10.7860/jcdr/2015/12062.5622

42. Gupta, D. K., Inouhe, M., Rodríguez-Serrano, M., Romero-Puertas, M. C., and Sandalio, L. M. (2013). Oxidative stress and arsenic toxicity: role of NADPH oxidases. Chemosphere 90 (6), 1987-1996. doi: 10.1016/j.chemosphere.2012.10.066

43. Haastrup, P. F., Thompson, W., Søndergaard, J., and JarbøI, D. E. (2018). Side effects of long-term proton pump inhibitor use: a review. Basic Clin. Pharmacol. Toxicol. 123 (2), 114-121. doi: 10.1111/bcpt.13023

44. Herbet, M., Izdebska, M., Piątkowska-Chmiel, I., Poleszak, E., and Jagiełło-Wójtowicz, E. (2016). Estimation of oxidative stress parameters in rats after simultaneous administration of rosuvastatin with antidepressants. Pharmacol. Rep. 68 (1), 172-176. doi: 10.1016/j.pharep.2015.08.004

45. Holland, N., Bolognesi, C., Kirsch-Volders, M., Bonassi, S., Zeiger, E., Knasmueller, S., and Fenech, M. (2008). The micronucleus assay in human buccal cells as a tool for biomonitoring DNA damage: the HUMN project perspective on current status and knowledge gaps. Mutat. Res. Rev. Mutat. Res. 659 (1-2), 93-108. doi: 10.1016/j.mrrev.2008.03.007

46. Hong, F., Wu, N., Zhou, Y., Ji, L., Chen, T., and Wang, L. (2017). Gastric toxicity involving alterations of gastritis-related protein expression in mice following long-term exposure to nano TiO2. Food Res. Int. 95, 38-45. doi: 10.1016/j.foodres.2017.02.013

47. Ishiguro, T., Ishiguro, M., Ishiguro, R., and Iwai, S. (2012). Cotreatment with dichloroacetate and omeprazole exhibits a synergistic antiproliferative effect on malignant tumors. Oncology lett. 3 (3), 726-728. doi: 10.3892/ol.2012.552

48. Keilberg, D., and Ottemann, K. M. (2016). How H elicobacter pylori senses, targets and interacts with the gastric epithelium. Environ. Microbiol. 18 (3), 791-806. doi: 10.1111/1462-2920.13222

49. Kim, Y. J., Lee, J. S., Hong, K. S., Chung, J. W., Kim, J. H., and Hahm, K. B. (2010). Novel application of proton pump inhibitor for the prevention of colitis-induced colorectal carcinogenesis beyond acid suppression. Cancer Prev. Res. 3 (8), 963-974. doi: 10.1158/1940-6207.CAPR-10-0033

50. Kohler, J. E., Blass, A. L., Liu, J., Tai, K., and Soybel, D. I. (2010). Antioxidant pre-treatment prevents omeprazole-induced toxicity in an in vitro model of infectious gastritis. Free. Radic. Biol. Med. 49 (5), 786-791. doi: 10.1016/j.freeradbiomed.2010.05.034

51. Kondratyev, A. D., Chung, K. N., and Jung, M. O. (1996). Identification and characterization of a radiation-inducible glycosylated human early-response gene. Cancer res. 56 (7), 1498-1502. 
52. Lahner, E., Galli, G., Esposito, G., Pilozzi, E., Corleto, V. D., and Annibale, B. (2014). Updated features associated with type 1 gastric carcinoids patients: a single-center study. Scand. J. Gastroenterol. 49 (12), 1447-1455. doi: 10.3109/00365521.2014.968859

53. Laskoski, L. M., Dittrich, R. L., Valadão, C. A. A., Brum, J. S., Brandão, Y., Brito, H. F. V., and de Sousa, R. S. (2016). Oxidative stress in hoof laminar tissue of horses with lethal gastrointestinal diseases. Vet. Immunol. Immunopathol. 171, 66-72. doi: 10.1016/j.vetimm.2016.02.008

54. Liu, X., He, Y., Li, F., Huang, Q., Kato, T. A., Hall, R. P., and Li, C. Y. (2016). Redefinindo os papéis dos fatores apoptóticos na carcinogênese. Oncologia molecular e cellular3 e1054550.

55. Lowry, O. H., Rosebrough, N. J., Farr, A. L., and Randal, R. J. (1951). Proteinmeasurementwith 665 Follinphenolreagent. J. Biol. Chem. 193, 265-275.

56. Lou, D. I., Hussmann, J. A., McBee, R. M., Acevedo, A., Andino, R., Press, W. H., and Sawyer, S. L. (2013). High-throughput DNA sequencing errors are reduced by orders of magnitude using circle sequencing. Proc. Natl Acad. Sci. 110 (49), 19872-19877. doi: 10.1073/pnas.1319590110

57. Luzhna, L., Kathiria, P., and Kovalchuk, O. (2013). Micronuclei in genotoxicity assessment: from genetics to epigenetics and beyond. Front. Genet. 4, 131. doi: 10.3389/fgene.2013.00131

58. Mahmoud-Awny, M., Attia, A. S., Abd-Ellah, M. F., and El-Abhar, H. S. (2015). Mangiferin mitigates gastric ulcer in ischemia/reperfused rats: involvement of PPAR- - , NF-KB and Nrf2/HO-1 signaling pathways. PloS one 10 (7), e0132497. doi: 10.1371/journal.pone.0132497

59. Marie, M. A. M., and Altahir, I. E. (2011). Relationship between the extent of DNA damage and gastritis in normal and Helicobacter pylori-infected patients. Gut liver 5(3), 315. doi: 10.5009/gnl.2011.5.3.315

60. Marino, M. L., Fais, S., Djavaheri-Mergny, M., Villa, A., Meschini, S., Lozupone, F., et al. (2010). Proton pump inhibition induces autophagy as a survival mechanism following oxidative stress in human melanoma cells. Cell Death Dis. 1 (10), e87-e87. doi: 10.1038/cddis.2010.67

61. Minalyan, A., Benhammou, J. N., Artashesyan, A., Lewis, M. S., and Pisegna, J. R. (2017). Autoimmune atrophic gastritis: current perspectives. Clin. Exp. Gastroenterol. 10, 19-27. doi: 10.2147/ceg.s109123

62. Moloney, J. N., and Cotter, T. G. (2018). ROS signalling in the biology of cancer. Semin. Cell Dev. Biol. 80, 50-64. doi: 10.1016/j.semcdb.2017.05.023

63. Morimura, T., Fujita, K., Akita, M., Nagashima, M., and Satomi, A. (2008). The proton pump inhibitor inhibits cell growth and induces apoptosis in human hepatoblastoma. Pediatr. Surg. Int. 24 (10), 1087-1094.doi: 10.1007/s00383-008-2229-2

64. Müerköster, S. S., Rausch, A. V., Isberner, A., Minkenberg, J., Blaszczuk, E., Witt, M., et al. (2008). The apoptosis-inducing effect of gastrin on colorectal cancer cells relates to an increased IEX-1 expression mediating NF-K B inhibition. Oncogene 27 (8), 1122-1134. doi: 10.1038/sj.onc. 1210728

65. Müerköster, S., Isberner, A., Arlt, A., Witt, M., Reimann, B., Blaszczuk, E., et al. (2005). Gastrin suppresses growth of CCK2 receptor expressing colon cancer cells by inducing apoptosis in vitro and in vivo. Gastroenterology 129 (3), 952-968. doi: 10.1053/j.gastro.2005.06.059 
66. Novotna, A., Srovnalova, A., Svecarova, M., Korhonova, M., Bartonkova, I., and Dvorak, Z. (2014). Differential effects of omeprazole and lansoprazole enantiomers on aryl hydrocarbon receptor in human hepatocytes and cell lines. PloS one 9 (6), e98711. doi: 10.1371/journal.pone.0098711

67. Numico, G., Fusco, V., Franco, P., and Roila, F. (2017). Proton pump inhibitors in cancer patients: how useful they are? A review of the most common indications for their use. Crit. Rev. Oncol. Hematol. 111, 144-151. doi: 10.1016/j.critrevonc.2017.01.014

68. Park, S., Hyun, Y. J., Kim, Y. R., Lee, J. H., Ryu, S., Kim, J. M., et al. (2017). Effects of CYP2C19 genetic polymorphisms on PK/PD responses of omeprazole in Korean healthy volunteers. J. Korean. Med. Sci. 32 (5), 729-736. doi: 10.3346/jkms.2017.32.5.729

69. Patel, A., Zhang, S., Shrestha, A. K., Maturu, P., Moorthy, B., and Shivanna, B. (2016). Omeprazole induces heme oxygenase- 1 in fetal human pulmonary microvascular endothelial cells via hydrogen peroxide-independent Nrf2 signaling pathway. Toxicol. Appl. Pharmacol. 311, 26-33. doi: 10.1016/j.taap.2016.10.002

70. Patel, A., Zhang, S., Moorthy, B., and Shivanna, B. (2015). Omeprazole does not potentiate acute oxygen toxicity in fetal human pulmonary microvascular endothelial cells exposed to hyperoxia. Pharm. Anal. Acta 6, 424. doi: 10.4172/2153-2435.1000424

71. Patlolla, J. M., Zhang, Y., Li, Q., STEEIE, V. E., and Rao, C. V. (2012). Anti-carcinogenic properties of omeprazole against human colon cancer cells and azoxymethane-induced colonic aberrant crypt foci formation in rats. Int. J. Oncol. 40 (1), 170-175. doi: 10.3892/ijo.2011.1214

72. Paz, M. F. C. J., Braga, A. L., de Meneses, A. A. P. M., de Carvalho, R. M., de Aguiar, R. P. S., Cronemberger, L. A. C., et al. (2019). Ascorbic acid and retinol palmitate modulatory effect on omeprazole-induced oxidative damage, and the cytogenetic changes in S. cerevisiae and S180 cells. Chemico-biological interactions, 311, 108776. doi: 10.1016/j.cbi.2019.108776

73. Pey, A., Zamoum, T., Christen, R., Merle, P. L., and Furla, P. (2017). Characterization of glutathione peroxidase diversity in the symbiotic sea anemone Anemonia viridis. Biochimie 132, 94-101. doi: 10.1016/j.biochi.2016.10.016

74. Phillips, D. H., Hewer, A., and Osborne, M. R. (1992). Interaction of omeprazole with DNA in rat tissues. Mutagenesis 7 (4), 277-283.doi: 10.1093/mutage/7.4.277

75. Pittaluga, M., Sgadari, A., Dimauro, I., Tavazzi, B., Parisi, P., and Caporossi, D. (2015). Physical exercise and redox balance in type 2 diabetics: effects of moderate training on biomarkers of oxidative stress and DNA damage evaluated through comet assay. Oxid. Med. Cell Longev. 2015.doi: $10.1155 / 2015 / 981242$

76. Poprac, P., Jomova, K., Simunkova, M., Kollar, V., Rhodes, C. J., and Valko, M. (2017). Targeting free radicals in oxidative stress-related human diseases. Trends Pharmacol. Sci. 38 (7), 592-607. doi: 10.1016/j.tips.2017.04.005

77. Porto, M. L., Lírio, L. M., Dias, A. T., Batista, A. T., Campagnaro, B. P., Mill, J. G., et al. (2015). Increased oxidative stress and apoptosis in peripheral blood mononuclear cells of fructose-fed rats. Toxicol. In Vitro 29 (8), 1977-1981. doi: 10.1016/j.tiv.2015.08.006 
78. Powers, R. E., Lawton, G. P., and Modlin, I. M. (1995). Genotoxicity, carcinogenicity and acidsuppressing medications. Pharmacol. Ther. 65 (3), 303-317. doi: 10.1016/0163-7258(95)98596-i

79. Rim, K. T., and Kim, S. J. (2015). A review on mutagenicity testing for hazard classification of chemicals at work: focusing on in vivo micronucleus test for allyl chloride. Saf. Health Work 6 (3), 184-191.doi: 10.1016/j.shaw.2015.05.005

80. Rosenkranz, H. S., and Klopman, G. (1991). Omeprazole: an exploration of its reported genotoxicity. Mutagenesis6 (5), 381-384. doi: 10.1093/mutage/6.5.381

81. Sabharwal, R., Verma, P., Syed, M. A., Sharma, T., Subudhi, S. K., Mohanty, S., and Gupta, S. (2015). Emergence of micronuclei as a genomic biomarker. Indian J. Med. Paediatr. Oncol. 36 (4), 212-218. doi: 10.4103/0971-5851.171541

82. Sagari, S. G., Babannavar, R., Lohra, A., Kodgi, A., Bapure, S., and Rao, Y. (2014). Micronuclei frequencies and nuclear abnormalities in oral exfoliated cells of nuclear power plant workers. J. Clin. Diagn. Res. 8 (12), ZC15-ZC17. doi:10.7860/JCDR/2014/9059.5240

83. Savarino, V., Dulbecco, P., De Bortoli, N., Ottonello, A., and Savarino, E. (2017). The appropriate use of proton pump inhibitors (PPIs): need for a reappraisal. Eur. J. Intern. Med. 37, 19-24. doi: 10.1016/j.ejim.2016.10.007

84. Scaringi, L., Cornacchione, P., Ayroldi, E., Corazzi, L., Capodicasa, E., Rossi, R., and Marconi, P. (2004). Omeprazole induces apoptosis in jurkat cells. Int. J. Immunopathol. Pharmacol. 17 (3), 331-342.

85. Seoane, M., Esperanza, M., and Cid, Á. (2017). Cytotoxic effects of the proton pump inhibitor omeprazole on the non-target marine microalga Tetraselmis suecica. Aquat. Toxicol. 191, 62-72. doi: 10.1016/j.aquatox.2017.08.001

86. Shankar, G., Borkar, R. M., Udutha, S., Kanakaraju, M., Charan, G. S., Misra, S., and Srinivas, R. (2019). Identification and structural characterization of the stress degradation products of omeprazole using Q-TOF-LC-ESI-MS/MS and NMR experiments: evaluation of the toxicity of the degradation products. New J. Chem. 43 (19), 7294-7306. doi:10.1039/C9NJ00932A

87. Sies, H. (2017). Hydrogen peroxide as a central redox signaling molecule in physiological oxidative stress: Oxidative eustress. Redox Biol. 11, 613-619. doi: 10.1016/j.redox.2016.12.035

88. Sofidiya, M. O., Agufobi, L., Akindele, A. J., Olowe, J. A., and Familoni, O. B. (2012). Effect of Flabellaria paniculata Cav. extracts on gastric ulcer in rats. BMC ComplementAltern. Med. 12 (1), 168. doi: 10.1186/1472-6882-12-168

89. Strand, D. S., Kim, D., and Peura, D. A. (2017). 25 years of proton pump inhibitors: a comprehensive review. Gut liver 11 (1), 27-37. doi:10.5009/gnl15502

90. Thomas, P., Holland, N., Bolognesi, C., Kirsch-Volders, M., Bonassi, S., Zeiger, E., et al. (2009). Buccal micronucleus cytome assay. Nat. Protoc. 4 (6), 825-837. doi:10.1038/nprot.2009.53

91. Thongon, N., and Krishnamra, N. (2011). Omeprazole decreases magnesium transport across Caco-2 monolayers. World J. Gastroenterol.17 (12), 1574-1583. doi: 10.3748/wjg.v17.i12.1574

92. Tonazzi, A., Console, L., and Indiveri, C. (2013). Inhibition of mitochondrial carnitine/acylcarnitine transporter by H2O2: Molecular mechanism and possible implication in pathophysiology. Chem. Biol. 
Interact. 203(2), 423-429.doi: 10.1016/j.cbi.2013.01.006

93. Thomas, B., Mohamed, M., Al Hail, M., Awwad, F. A. Y., Wahba, R. M., Hassan, S. B., et al. (2016). A case of probable esomeprazole-induced transient liver injury in a pregnant woman with hyperemesis. Clin Pharmacol. 8, 199-202.doi: 10.2147/cpaa.s106234

94. Trindade, L. M. D. F., de Oliveira Menezes, L. B., de Souza Neta, A. M., Rolemberg, P. C. L., Souza, L. D., de Carvalho Barreto, I. D., and Meurer, L. (2017). Prevalence of Helicobacter pylori infection in samples of gastric biopsies. Gastroenterology Res. 10(1), 33-41.doi: 10.14740/gr785w

95. Tsuchiya, T., Kijima, A., Ishii, Y., Takasu, S., Yokoo, Y., Nishikawa, A., et al. (2018). Mechanisms of oxidative stress-induced in vivo mutagenicity by potassium bromate and nitrofurantoin. J. Toxicol. Pathol. 31 (3), 179-188. doi: 10.1293/tox.2018-0024

96. Xiao, X., Wu, Z. C., and Chou, K. C. (2011). A multi-label classifier for predicting the subcellular localization of gram-negative bacterial proteins with both single and multiple sites. PloS one 6 (6), e20592. doi: 10.1371/journal.pone.0020592

97. Uotani, T., and Graham, D. Y. (2015). Diagnosis of Helicobacter pylori using the rapid urease test. Ann. Transl. Med. 3 (1), 9. doi: 10.3978/j.issn.2305-5839.2014.12.04

98. Ward, W. M., Hoffman, J. D., and Loo, G. (2015). Genotoxic effect of ethacrynic acid and impact of antioxidants. Toxicol. Appl. Pharmacol. 286 (1), 17-26. doi: 10.1016/j.taap.2015.03.016

99. Wessler, S., Krisch, L. M., Elmer, D. P., and Aberger, F. (2017). From inflammation to gastric cancer-the importance of Hedgehog/GLI signaling in Helicobacter pylori-induced chronic inflammatory and neoplastic diseases. Cell Commun. Signal. 15 (1), 1-13. doi: 10.1186/s12964-017-0171-4

100. Woźniak, A., Walawender, M., Tempka, D., Coy, E., Załęski, K., Grześkowiak, B. F., and Mrówczyński, R. (2017). In vitro genotoxicity and cytotoxicity of polydopamine-coated magnetic nanostructures. Toxicol. In Vitro, 44, 256-265. doi: 10.1016/j.tiv.2017.07.022

101. Yu, L. Y., Sun, L. N., Zhang, X. H., Li, Y. Q., Yu, L., Meng, L., et al. (2017). A review of the novel application and potential adverse effects of proton pump inhibitors. Adv. Ther. 34 (5), 1070-1086. doi:10.1007/s12325-017-0532-9

102. Zhang, J. L., Liu, M., Yang, Q., Lin, S. Y., Shan, H. B., Wang, H. Y., and Xu, G. L. (2017). Effects of omeprazole in improving concurrent chemoradiotherapy efficacy in rectal cancer. World J. Gastroenterol. 23 (14), 2575-2584. doi:10.3748/wjg.v23.i14.2575

103. Zheng, H., Chen, Y., Zhang, J., Wang, L., Jin, Z., Huang, H., et al. (2016). Evaluation of protective effects of costunolide and dehydrocostuslactone on ethanol-induced gastric ulcer in mice based on multi-pathway regulation. Chem. Biol. Interact. 250, 68-77. 10.1016/j.cbi.2016.03.003

\section{Figures}




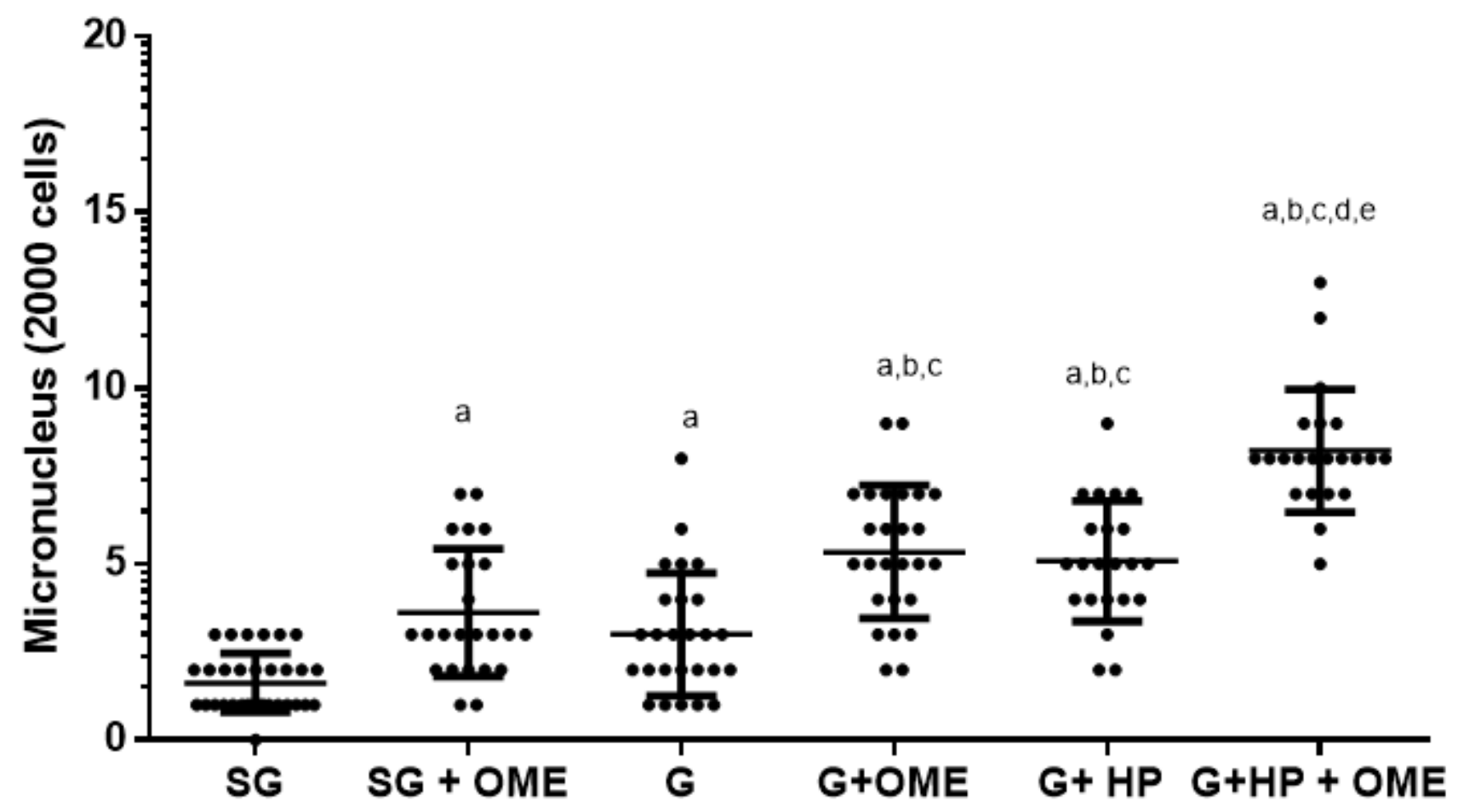

Figure 1

Clastogenic and/or aneugenic and cytotoxic effects of the induction of micronuclei and binucleated cells in 2000 stomach epithelial cells. (A) MN, (B) binucleated, WG (Without Gastritis, $n=32$ ); (Without Gastritis + OME, $n=24), G$ (Gastritis-n = 26); $G$ + OME (Gastritis + OME, $n=26), G$ + HP (Gastritis + H. pylori, $n=$ 22); $W G+O M E G+H P+O M E$ (Gastritis + H. pylori + OME, $n=22)$. Values represent the mean \pm S.D.M. Differences between groups were determined by Analysis of Variance (ANOVA, and Bonferroni's test (post hoc test). Significances were observed for $<0.05$ and $p<0.0001$, a in relation to $W G, b$ in relation to $S G+$ $\mathrm{OME}, \mathrm{c}$ in relation to $\mathrm{G}, \mathrm{d}$ in relation to $\mathrm{G}+\mathrm{OME}$ and $\mathrm{e}$ in relation to $\mathrm{G}+\mathrm{HP}$.
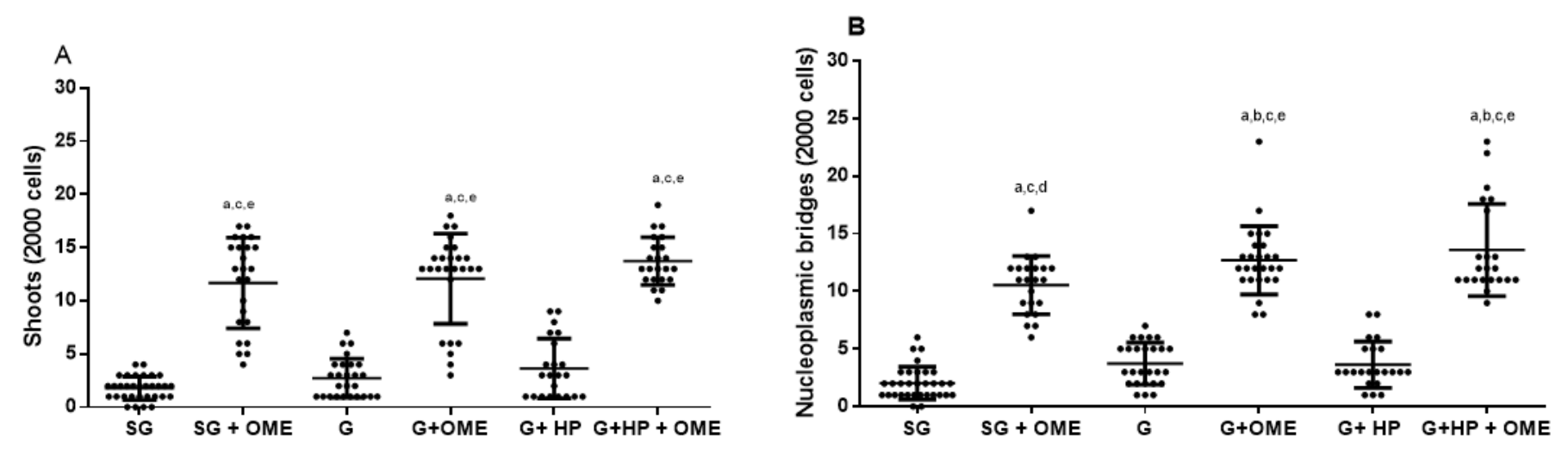

Figure 2 
Cytogenetic risks of therapy as OME in patients with gastritis, by inducing buds $(A)$ and bridges $(B)$ in the evaluation of 2000 oral epithelial cells. WG (Without Gastritis, $n=32$ ); (Without Gastritis $+O M E, n=24$ ), $G$ (Gastritis- $n=26) ; \mathrm{G}+\mathrm{OME}$ (Gastritis + OME, $n=26), \mathrm{G}+\mathrm{HP}$ (Gastritis + H. pylori, $n=22) ; \mathrm{WG}+\mathrm{OME} \mathrm{G}+$ $H P+O M E($ Gastritis $+H$. pylori+ OME, $n=22)$. Values represent the mean \pm S.E.M. Differences between groups were determined by Analysis of Variance (ANOVA, and Bonferroni's test (post hoc test).

Significances were observed for $<0.05$ and $p<0.0001, a, b, c$, d, and e in relation to $W G, S G+O M E, G$, and $\mathrm{G}+\mathrm{OME}$, and e $\mathrm{G}+\mathrm{HP}$, respectively.
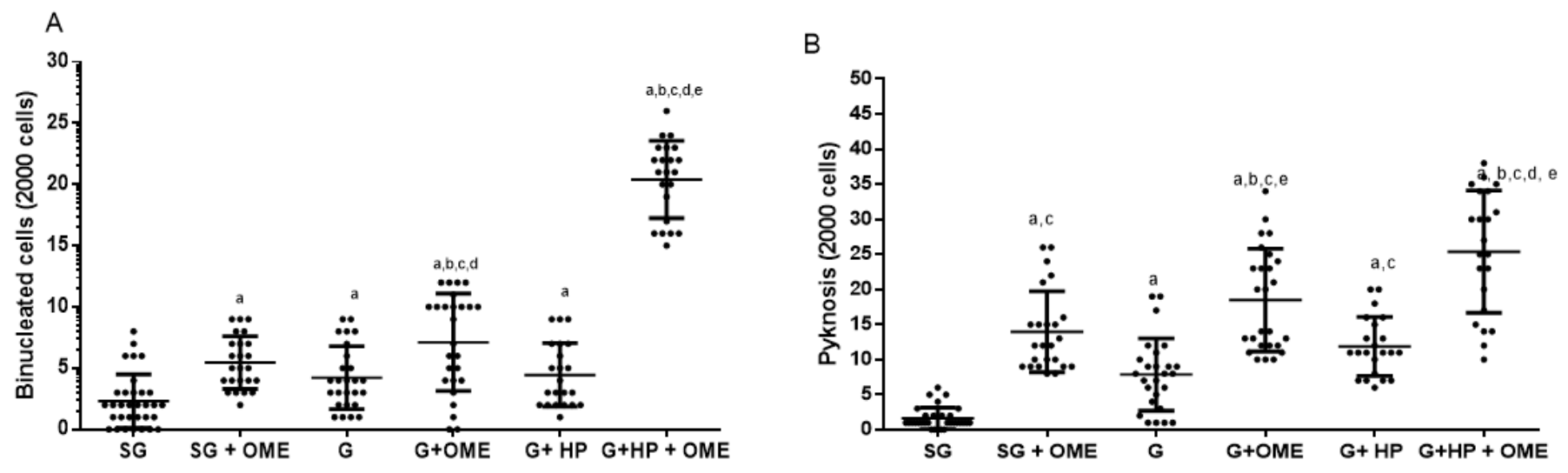

Figure 3

Cytogenetic changes indicative of cytotoxicity in the stomach epithelium of patients submitted therapy with omeprazole (OME) by the formation of (A) binucleated cells and (B) picnoses. WG (Without Gastritis, $n=32) ; W G$ + OME (Without Gastritis + OME, $n=24), G$ (Gastritis- $n=26) ; ~ G+O M E$ (Gastritis + OME, $n=$ 26), $G+H P$ (Gastritis + H. pylori, $n=22) ; G+H P+O M E$ (Gastritis + H. pylori + OME, $n=22)$. Values represent the mean \pm S.D.M. The differences between the groups were determined by Analysis of Variance (ANOVA, followed by the Bonferroni test (post hoc test).Significances were observed for $p$ $<0.0001, a, b, c, d$, and e in relatated to $S G, S G+O M E, G, d$ G + OME, and G + HP, respectively. 


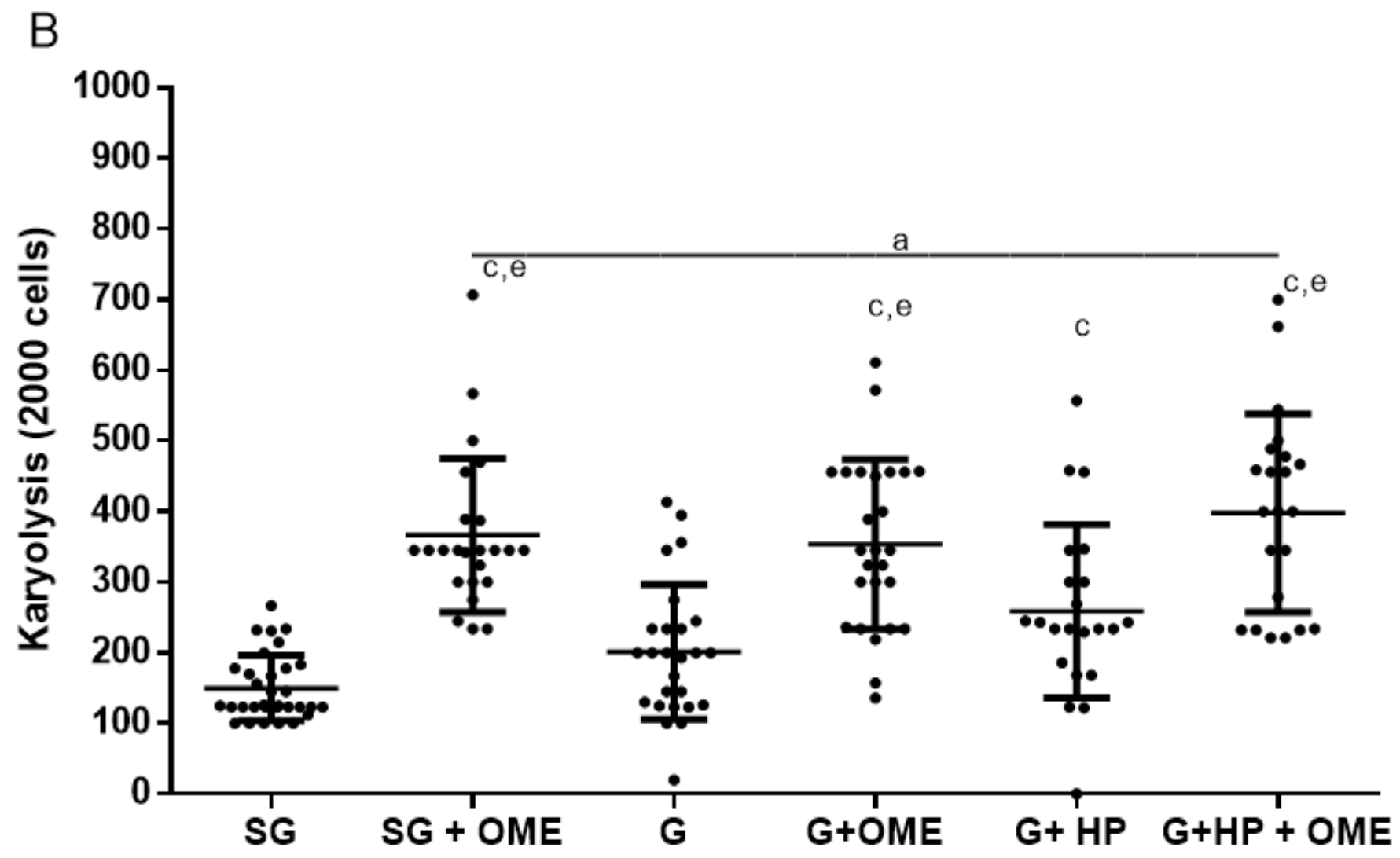

Figure 4

Cytogenetic changes indicative of apoptosis in the epithelium of the stomach of patients undergoing therapy with Omeprazole (OME) by the formation of (A: Not included with this version) karyorexis and (B) karyolysis. SG (Without Gastritis, $n=32$ ); SG + OME (Without Gastritis + OME, $n=24)$, G (Gastritis- $n=26$ ); $\mathrm{G}+\mathrm{OME}$ (Gastritis + OME, $\mathrm{n}=26), \mathrm{G}+\mathrm{HP}$ (Gastritis + H.pylori, $\mathrm{n}=22) ; \mathrm{G}+\mathrm{HP}+\mathrm{OME}$ (Gastritis + H.pylori $+O M E, n=22)$. Values represent the mean \pm S.D.M. Differences between groups were determined by Analysis of Variance (ANOVA, followed by the Bonferroni test (post hoc test). Significances for $p<0.0001$. $a, b, c, d$, and e in relation to $S G, S G+O M E, G, G+O M E$, and $G+H P$, respectively. 

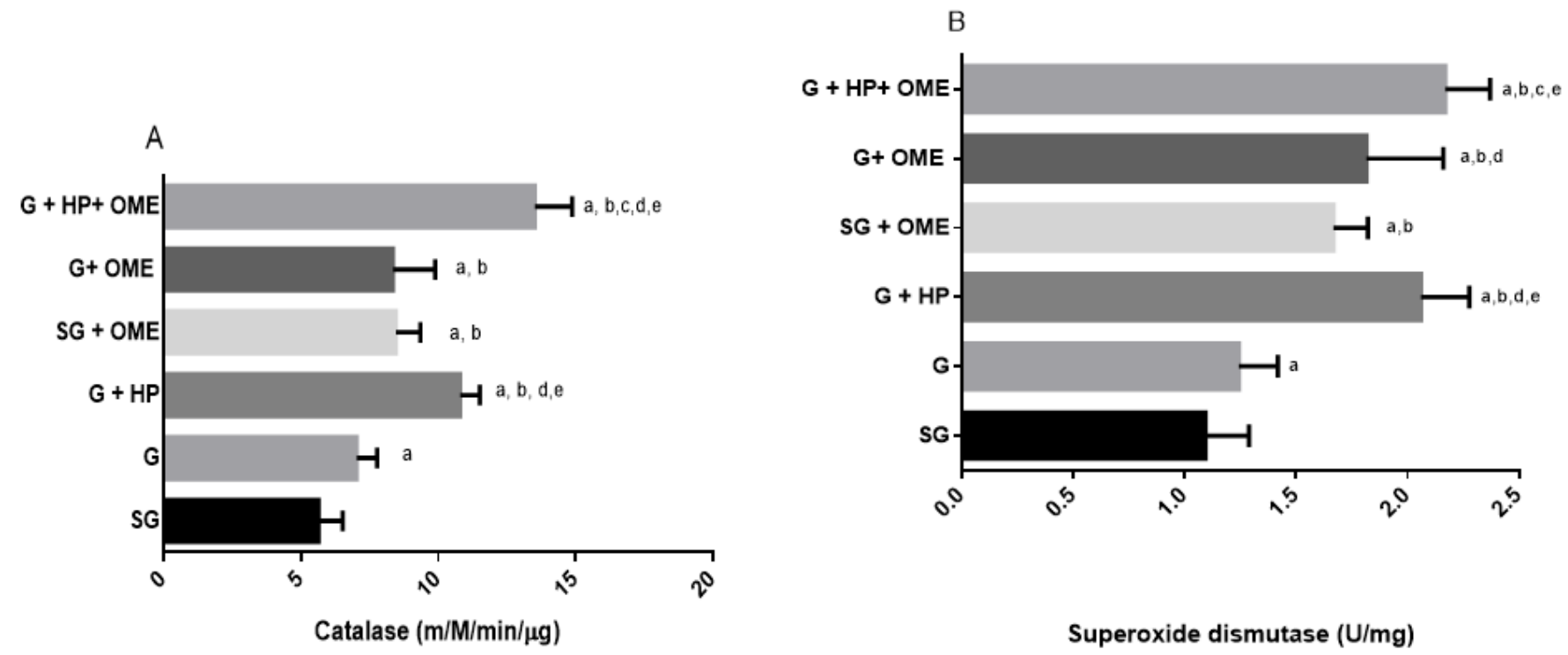

Figure 5

Changes in antioxidant enzyme dosages during omeprazole therapy (OME-40mg) in patients with negative and positive endoscopic diagnosedto gastritis. (A) Catalase and (B) superoxide dismutase. WG (Without Gastritis, $n=46$ ); (Without Gastritis + OME, n = 22), G (Gastritis-n = 48); G + OME (Gastritis + OME, $n=48), G+H P$ (Gastritis + H.pylori, $n=27) ; W G$ + OME G + HP + OME (Gastritis + H.pylori + OME, $n$ $=27$ ). Values represent the mean \pm S.D.M. Differences between groups were determined by Analysis of Variance (ANOVA, followed by the Bonferroni test (post hoc test). Significances were observed for $p<0.05$ and $p<0.0001, a, b, c, d$, and e in relation to $W G, G, G+H P, W G+O M E$, and $G+O M E$, respectively. 

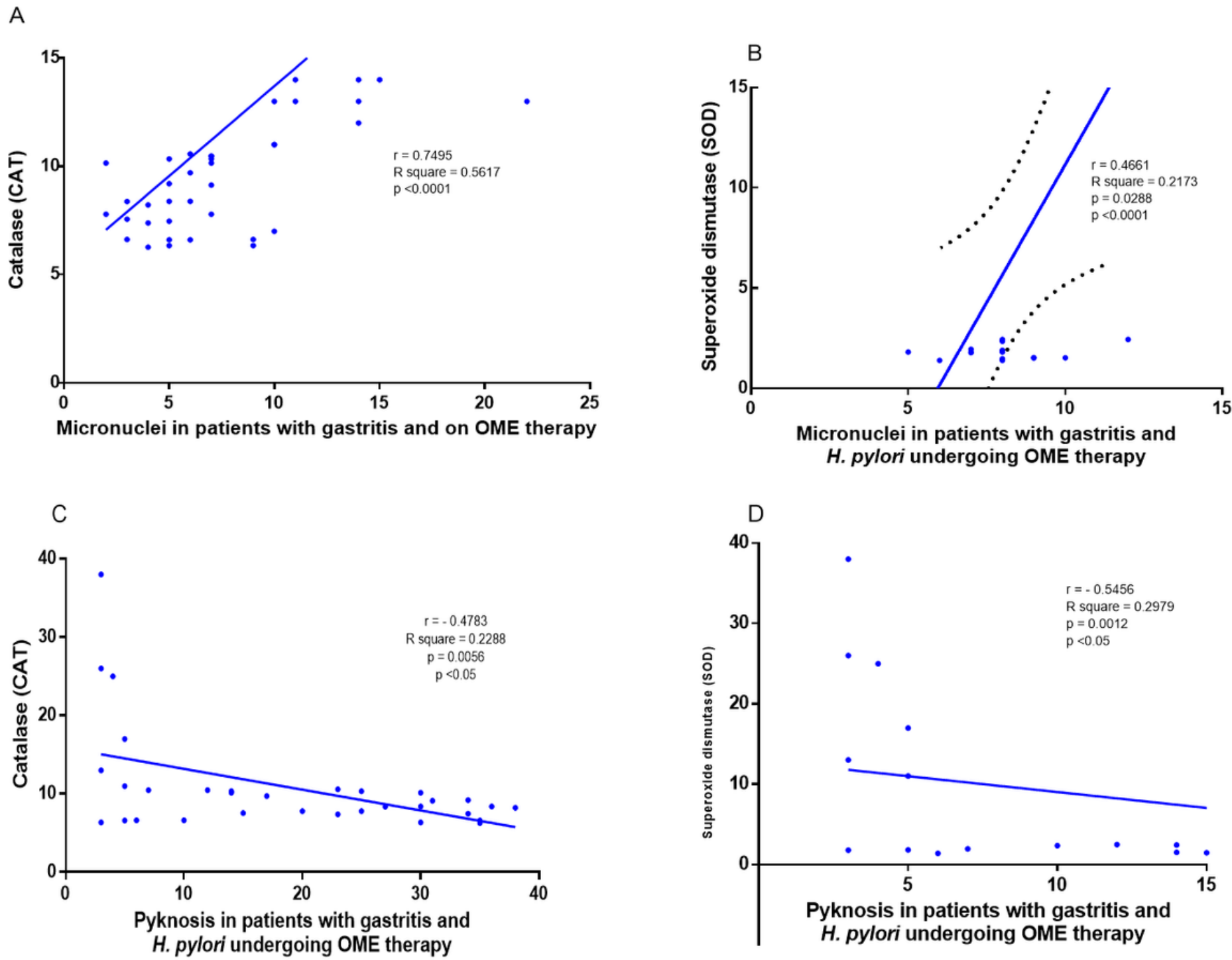

\section{Figure 6}

Pearson's statistical correlations between cytogenetic biomarkers and antioxidant enzymes for micronuclei and catalase (A); micronuclei and superoxide dismutase (B); pycnosis and catalase (C) and (D) pycnosis and superoxide dismutases (D). WG (Without Gastritis, $n=46$ ); (Without Gastritis + OME, $n=$ 22), G (Gastritis-n = 48); G + OME (Gastritis + OME, $n=48), \mathrm{G}+\mathrm{HP}$ (Gastritis + H.pylori, $n=27$ ); WG + $\mathrm{OME} \mathrm{G}+\mathrm{HP}+\mathrm{OME}$ (Gastritis + H.pylori + OME, $n=27)$. 

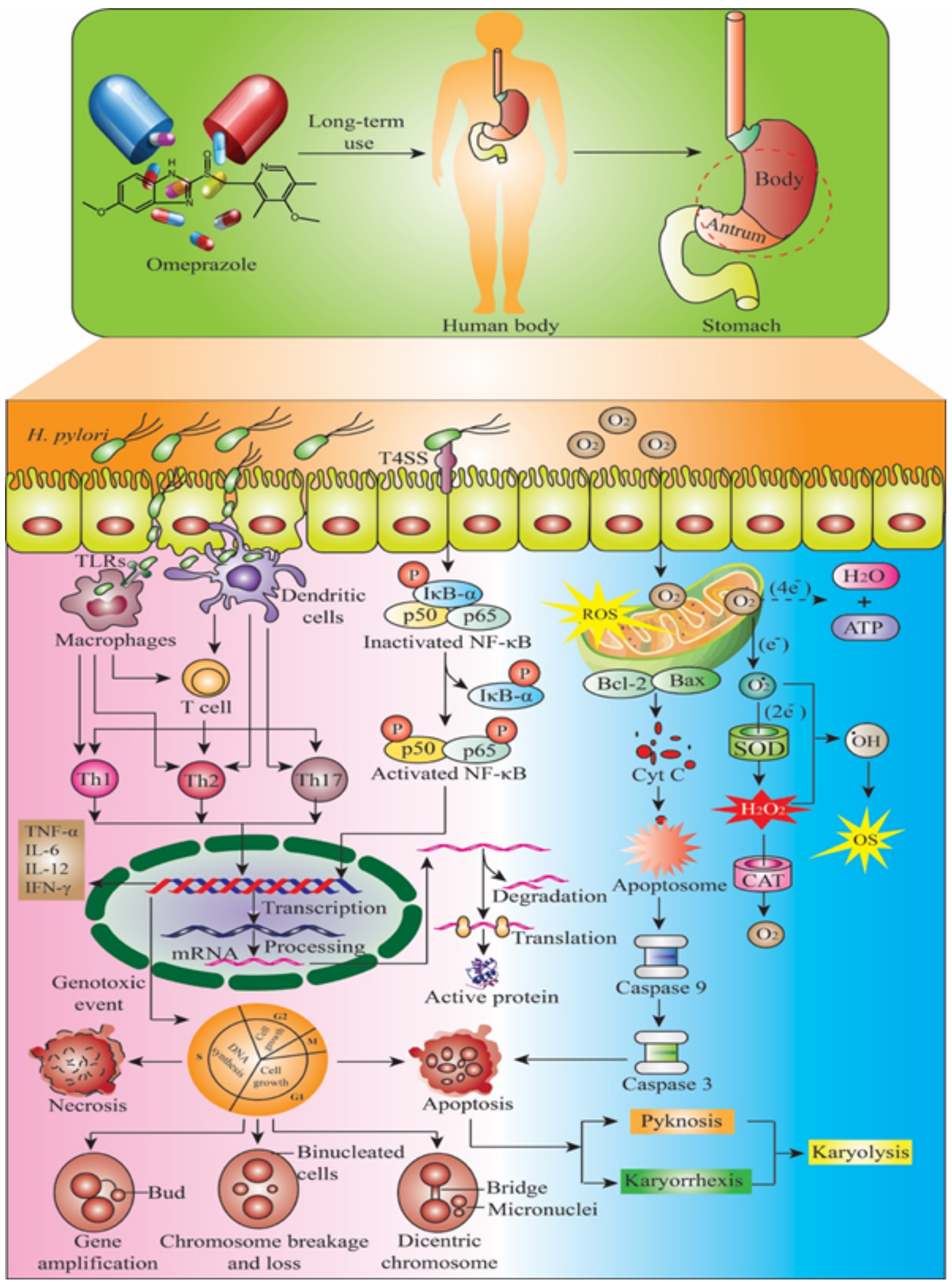

Figure 7

Possible mutagenic, apoptosis and necrosis effects of omeprazole OME. [ATP- adenosine triphosphate; CAT- catalase; І $\mathrm{KBa}$, nuclear factor of kappa light polypeptide gene enhancer in B-cells inhibitor, alpha; NFKB- nuclear factor kappa-light-chain-enhancer of activated B cells; OS- oxidative stress; SOD- superoxide dismutase] 